\title{
Clozapine and Haloperidol Differently Suppress the MK-80I-Increased Glutamatergic and Serotonergic Transmission in the Medial Prefrontal Cortex of the Rat
}

\author{
Xavier López-Gil', Zoila Babot', Mercè Amargós-Bosch', Cristina Suñol', Francesc Artigas' \\ and Albert Adell*,I \\ 'Department of Neurochemistry and Neuropharmacology, Instituto de Investigaciones Biomédicas de Barcelona, CSIC (IDIBAPS), Barcelona, \\ Spain
}

\begin{abstract}
The administration of noncompetitive N-methyl-D-aspartate (NMDA) receptor antagonists such as phencyclidine and ketamine has been shown to increase the extracellular concentration of glutamate and serotonin (5-HT) in the medial prefrontal cortex (mPFC). In the present work, we used in vivo microdialysis to examine the effects of the more potent noncompetitive NMDA receptor antagonist, MK$80 \mathrm{I}$, on the efflux of glutamate and 5-HT in the mPFC, and whether the MK-80I-induced changes in the cortical efflux of both transmitters could be blocked by clozapine and haloperidol given systemically or intra-mPFC. The systemic, but not the local administration of MK-80I, induced an increased efflux of 5-HT and glutamate, which suggests that the NMDA receptors responsible for these effects are located outside the mPFC, possibly in GABAergic neurons that tonically inhibit glutamatergic inputs to the mPFC. The MK-80 I-induced increases of extracellular glutamate and 5-HT were dependent on nerve impulse and the activation of mPFC AMPA/ kainate receptors as they were blocked by tetrodotoxin and NBQX, respectively. Clozapine and haloperidol blocked the MK-80Iinduced increase in glutamate, whereas only clozapine was able to block the increased efflux of 5-HT. The local effects of clozapine and haloperidol paralleled those observed after systemic administration, which emphasizes the relevance of the mPFC as a site of action of these antipsychotic drugs in offsetting the neurochemical effects of MK-80I. The ability of clozapine to block excessive cortical 5-HT efflux elicited by MK-80 I might be related to the superior efficacy of this drug in treating negative/cognitive symptoms of schizophrenia. Neuropsychopharmacology (2007) 32, 2087-2097; doi:I0.I038/sj.npp. I 30 I356; published online I4 March 2007
\end{abstract}

Keywords: schizophrenia; clozapine; haloperidol; MK-80 I; serotonin; glutamate

\section{INTRODUCTION}

The acute administration of noncompetitive $\mathrm{N}$-methylD-aspartate (NMDA) receptor antagonists such as phencyclidine (PCP) and ketamine has been considered as a pharmacological model of schizophrenia because these drugs can evoke positive and negative symptoms as well as characteristic cognitive deficits that closely resemble those of the illness (Javitt and Zukin, 1991; Krystal et al, 1994; Malhotra et al, 1994; Newcomer et al, 1999). For this reason, schizophrenia has been associated with NMDA receptor hypofunction (Javitt and Zukin, 1991; Tamminga, 1998). In rats, PCP and the more potent and selective noncompetitive NMDA antagonist, dizocilpine (MK-801), bring about hyperlocomotion and stereotypies (Hertel et al,

*Correspondence: Dr A Adell, Department of Neurochemistry and Neuropharmacology, Instituto de Investigaciones Biomédicas de Barcelona, CSIC (IDIBAPS), Calle Rosellón 16I, 6th floor, Room 630, E-08036 Barcelona, Spain, Tel: + 3493 3638321, Fax: + 3493 363830 I, E-mail: aacnqi@iibb.csic.es

Received 8 March 2006; revised 14 December 2006; accepted I January 2007
1996; Adams and Moghadam, 2001; Homayoun et al, 2004). These behaviors are thought to result from increased dopaminergic and serotonergic activities (Giros et al, 1996; Jentsch et al, 1998; Lucki, 1998), and have been potentially related to positive symptoms of schizophrenia (Moghaddam and Adams, 1998; Jentsch and Roth, 1999; Mohn et al, 1999). Furthermore, the behavioral deficits observed in humans and rodents are distinctly responsive to clozapine (Bakshi et al, 1994; Maurel-Remy et al, 1995; Malhotra et al, 1997). Acute NMDA receptor antagonism has also been reported to increase the release of glutamate (Moghaddam et al, 1997; Adams and Moghadam, 2001; Lorrain et al, 2003), dopamine (Moghaddam and Adams, 1998; Mathé et al, 1999; Schmidt and Fadayel, 1996), and serotonin (5-HT) (Martin et al, 1998; Millan et al, 1999; Adams and Moghadam, 2001; Amargós-Bosch et al, 2006) in the medial prefrontal cortex (mPFC) of rats. These effects are coincident with an enhanced spontaneous firing rate of putative pyramidal neurons of the mPFC (Suzuki et al, 2002; Jackson et al, 2004). The increase in cortical glutamatergic transmission elicited through the blockade of an excitatory glutamate receptor (NMDA) may seem contradictory. 
However, it has been postulated that noncompetitive NMDA receptor antagonists may actually inhibit GABAergic inputs to glutamatergic neurons in the mPFC (Olney and Farber, 1995; Moghaddam et al, 1997; Krystal et al, 2003). In fact, GABAergic interneurons in limbic cortex and hippocampus are extremely responsive to NMDA receptor antagonists in comparison with pyramidal neurons (Grunze et al, 1996; Li et al, 2002), and PCP is able to reduce cortical GABAergic function (Yonezawa et al, 1998). It remains to be determined whether this feature can be applied to other GABAergic cells throughout the brain. Thus, theoretically, this glutamatergic disinhibition could occur in the mPFC and/or in areas sending glutamatergic projections to the mPFC. However, the intra-mPFC administration of PCP or ketamine was unable to elevate cell firing and locomotion (Suzuki et al, 2002) or increase extracellular 5-HT (Amargós-Bosch et al, 2006). Therefore, it appears that the NMDA receptors responsible for these effects are located outside the mPFC, possibly in GABA neurons that would tonically inhibit glutamatergic efferents in areas that project densely to $\mathrm{mPFC}$, such as hippocampus, thalamus, or amygdala.

In a previous work, we showed that acute PCP and ketamine enhanced extracellular 5-HT in the mPFC, and that this effect was blocked by systemic clozapine and olanzapine, but not by haloperidol (Amargós-Bosch et al, 2006). In the present study, we have tested the hypothesis that MK-801 would also increase serotonergic and glutamatergic transmission in the $\mathrm{mPFC}$ and examined the effects of clozapine and haloperidol, applied both systemically and intra-mPFC, on these neurochemical changes.

\section{MATERIALS AND METHODS}

\section{Animals}

Male Wistar rats (Iffa-Credo, Lyon, France) weighing 250$280 \mathrm{~g}$ were used. They were maintained on a $12 \mathrm{~h}$ light/dark cycle (lights on at 0700) and housed three per cage before surgery and individually after surgery. Food and water were always freely available. All experimental procedures were carried out in strict accordance with European Communities Council Directive on 'Protection of Animals Used in Experimental and Other Scientific Purposes' of 24 November 1986 (89/609/EEC), and were approved by the Institutional Animal Care and Use Committees. To reduce the influence of between-day variations on drug effects, most experimental groups were not completed at once, but along the duration of the whole work instead.

\section{Drugs and Reagents}

Dizocilpine maleate (MK-801), 2,3-dihydroxy-6-nitro-7sulfamoyl-benzo(f)quinoxaline (NBQX), 5-hydroxytryptamine oxalate, $o$-phthaldialdehyde (OPA) reagent (containing $1 \mathrm{mg}$ OPA per $\mathrm{ml}$ solution with 2-mercaptoethanol as the sulphydryl moiety), and glutamate were purchased from Sigma-Aldrich (Tres Cantos, Spain). Clozapine and tetrodotoxin (TTX) were from Tocris (Bristol, UK). Haloperidol was obtained as an injectable solution $(5 \mathrm{mg} / \mathrm{ml}$ dissolved in $0.5 \%$ lactic acid) from Laboratorios Esteve (Barcelona,
Spain). Citalopram hydrobromide was generously donated by H Lundbeck A/S (Copenhagen-Valby, Denmark).

MK-801 was dissolved in saline for intraperitoneal (i.p.) administration or in artificial cerebrospinal fluid (see below for composition) for local application through dialysis probes. Clozapine was dissolved in a few drops of glacial acetic acid and further diluted with saline for subcutaneous (s.c.) administration, or artificial cerebrospinal fluid for local application. For s.c. administration, haloperidol $(5 \mathrm{mg} / \mathrm{ml})$ was brought to $1 \mathrm{mg} / \mathrm{ml}$ by diluting five times the injectable solution with saline. When needed, the $\mathrm{pH}$ of the final concentrations was adjusted to 6.5-7.0 with $\mathrm{NaHCO}_{3}$. Appropriate vehicles were administered in control groups.

\section{Microdialysis Procedures}

Concentric dialysis probes with a 4 -mm long membrane were implanted under sodium pentobarbital anesthesia $(60 \mathrm{mg} / \mathrm{kg}$, i.p.) in the mPFC (AP $+3.2 \mathrm{~mm}, \mathrm{~L}-0.8 \mathrm{~mm}, \mathrm{DV}$ $-6.0 \mathrm{~mm}$; from bregma), according to Paxinos and Watson (1986). Microdialysis experiments were conducted $20-24 \mathrm{~h}$ after surgery in freely moving rats by continuously perfusing probes with artificial cerebrospinal fluid containing $125 \mathrm{mM} \mathrm{NaCl}, 2.5 \mathrm{mM} \mathrm{KCl}, 1.26 \mathrm{mM} \mathrm{CaCl}_{2}, 1.18 \mathrm{mM}$ $\mathrm{MgCl}_{2}$, and $1 \mu \mathrm{M}$ citalopram. The addition of an uptake inhibitor to the perfusion fluid is used in some microdialysis studies to decrease clearance from the extracellular space and magnify the release component of extracellular 5-HT (Adell et al, 2002). On the other hand, low concentrations of 5-HT uptake blockers, such as that used in the present study, are without effect on dialysate glutamate in vivo (Langman et al, 2006; Queiroz and Artigas, unpublished results). Interestingly, voltammetric studies have shown that MK-801 may interact with the serotonin transporter (Iravani et al, 1999; Callado et al, 2000), thereby underscoring the importance of including citalopram in the perfusion fluid.

The artificial cerebrospinal fluid was perfused at a rate of $1.5 \mu \mathrm{l} / \mathrm{min}$ with a WPI model sp220i syringe pump (WPI, Aston, Stevenage, UK) attached to an overhead liquid swivel (Instech, Plymouth Meeting, PA). Dialysate samples of $30 \mu \mathrm{l}$ were collected every $20 \mathrm{~min}$ and divided into two fractions for the determination of 5-HT $(20 \mu \mathrm{l})$ and glutamate $(10 \mu \mathrm{l})$. The in vitro dialysis probe recoveries for 5-HT and glutamate were 15 and $17 \%$, respectively. Owing to the incidental occurrence of chromatographic problems, for some rats data on only one transmitter (glutamate or 5-HT) were available. After a $100 \mathrm{~min}$ stabilization period, four dialysate samples were collected to obtain basal transmitter values (expressed as concentration of transmitter in a $30 \mu \mathrm{l}$ sample) before any pharmacological treatment. At the completion of dialysis experiments, rats were given an overdose of sodium pentobarbital and a fast green solution was perfused through the dialysis probes to stain the surrounding tissue for subsequent histological examination.

\section{Biochemical Determinations}

The concentration of 5-HT in dialysate samples was determined by an HPLC system consisting of a Waters 717plus autosampler (Waters Cromatografia, Cerdanyola, Spain), a Hewlett-Packard series 1050 pump (Agilent 
Technologies, Las Rozas, Spain), a $3-\mu \mathrm{M}$ octadecylsilica (ODS) column $(7.5 \mathrm{~cm} \times 0.46 \mathrm{~cm}$; Beckman, San Ramon, CA), and an amperometric detector Hewlett-Packard 1049 (Agilent Technologies) set at an oxidation potential of $0.6 \mathrm{~V}$. The mobile phase consisted of $0.15 \mathrm{M} \mathrm{NaH} \mathrm{PO}_{4}, 1.8 \mathrm{mM}$ octyl sodium sulfate, $0.2 \mathrm{mM}$ EDTA ( $\mathrm{pH} 2.8$, adjusted with phosphoric acid), and $30 \%$ methanol and was pumped at $0.7 \mathrm{ml} / \mathrm{min}$ (Adell and Artigas, 1998). For the determination of glutamate, another HPLC system was used, which consisted of a Waters 717plus autosampler, a Waters 600 quaternary gradient pump, and a Nucleosil 5- $\mu$ M ODS column $(10 \mathrm{~cm} \times 0.4 \mathrm{~cm}$; Teknokroma, Spain $)$. Dialysate samples were precolumn derivatized with OPA reagent and all this process was carried out by the autosampler. Briefly, $90 \mu \mathrm{l}$ distilled water was added to the $10 \mu \mathrm{l}$ dialysate sample and this was followed by the addition of $15 \mu \mathrm{l}$ of the OPA reagent. After $2.5 \mathrm{~min}$ reaction, $80 \mu \mathrm{l}$ of this mixture was injected into the column. Detection was carried out with a Waters 470 Scanning Fluorescence Detector using excitation and emission wavelengths of 360 and $450 \mathrm{~nm}$, respectively. The mobile phase consisted of $0.1 \mathrm{M}$ sodium acetate, $5.5 \mathrm{mM}$ triethylamine ( $\mathrm{pH} 5.5$ ) containing $10-70 \%$ acetonitrile and was pumped at $0.8 \mathrm{ml} / \mathrm{min}$ (Babot et al, 2005). The detection limits for 5-HT and glutamate were $4 \mathrm{fmol}$ and $0.3 \mathrm{pmol}$, respectively (signal-to-noise ratio 3 ).

\section{Statistics}

Data (mean \pm SEM) are expressed as fmol/30 $\mu \mathrm{l}$ for 5 -HT and $\mathrm{pmol} / 30 \mu \mathrm{l}$ for glutamate, and shown in figures as percentages of basal values, averaged from four fractions collected before treatment. Unless otherwise stated, the changes in dialysate 5-HT and glutamate were analyzed by two-way repeated measures analysis of variance (ANOVA) with time and treatment as factors. When significant effects were found, post hoc Newman-Keuls multiple comparison tests were used to compare effects of different treatment groups. In some cases areas under the curve (AUC) of selected time intervals were calculated and compared using ANOVA followed by post hoc Newman-Keuls tests, where appropriated. The level of significance was set at $p<0.05$.

\section{RESULTS}

The basal (predrug) concentrations of 5-HT and glutamate in dialysate samples of the mPFC, not corrected for in vitro recovery, were $50.3 \pm 1.8 \mathrm{fmol} / 30 \mu \mathrm{l}(n=155)$ and $7.2 \pm 0.6 \mathrm{pmol} / 30 \mu \mathrm{l}(n=164)$, respectively.

\section{Effects of MK-801}

As described previously in the literature (Homayoun et al, 2004; Jackson et al, 2004) the systemic administration of MK-801 to rats evoked marked hyperlocomotion and stereotypies (behavioral observation). Two-way ANOVA showed that with respect to saline-injected group, the administration of MK-801 (0.5-1 mg/kg, i.p.) enhanced dose dependently the extracellular concentration of 5-HT (Figure 1a) as demonstrated by the significant effect of treatment $\left(\mathrm{F}_{2,20}=12.5, p<0.0005\right)$, time $\left(\mathrm{F}_{15,300}=5.9\right.$, $p<0.00001)$, and treatment $\times$ time interaction $\left(\mathrm{F}_{30,300}=\right.$ 3.3, $p<0.00001)$. Post hoc comparisons showed that the increase elicited by $1 \mathrm{mg} / \mathrm{kg}$ MK- 801 was higher than that of $0.5 \mathrm{mg} / \mathrm{kg}(p<0.05$; Newman-Keuls test). The systemic administration of MK-801 also increased extracellular glutamate (Figure $1 \mathrm{~b}$ ), as shown by the significant effect of treatment $\left(\mathrm{F}_{2,15}=15.0, p<0.0003\right)$, time $\left(\mathrm{F}_{15,225}=5.0\right.$, $p<0.00001)$, and treatment $\times$ time interaction $\left(\mathrm{F}_{30,225}=4.6\right.$, $p<0.00001)$. However, only the dose of $1.0 \mathrm{mg} / \mathrm{kg} \mathrm{MK}-801$ significantly increased dialysate glutamate $(p<0.001$; Newman-Keuls test). For this reason, this latter dose was used for subsequent experiments. As described before for PCP (Adams and Moghadam, 2001), glutamate increased more slowly than 5-HT after MK-801 administration. On the contrary, the intra-mPFC perfusion of MK-801 at 30, 100, and $300 \mu \mathrm{M}$ for $80 \mathrm{~min}$ was without effect on dialysate 5-HT and glutamate (Figure 1c). To exclude any possible delayed effect of intracortical MK-801, a further experiment was carried out in which a concentration of $300 \mu \mathrm{M}$ of the compound was perfused through the dialysis probe for $4 \mathrm{~h}$. This long perfusion of MK-801 did not alter the concentrations of 5-HT and glutamate in the mPFC (Figure 1d). The local application of the AMPA/kainate antagonist, NBQX $(300 \mu \mathrm{M})$, suppressed the MK-801-induced increase in 5-HT $\left(\mathrm{F}_{1,12}=9.2, p<0.02\right.$; Figure $\left.1 \mathrm{a}\right)$ and glutamate $\left(\mathrm{F}_{1,10}=6.7, p<0.03\right.$; Figure $\left.1 \mathrm{~b}\right)$. When given alone, NBQX did not change 5-HT and glutamate levels in comparison to the corresponding control group. TTX $(1 \mu \mathrm{M})$ also suppressed MK-801-induced increase in 5-HT $\left(\mathrm{F}_{1,12}=136.2\right.$, $p<0.00001$; Figure 1a) and glutamate $\left(\mathrm{F}_{1,14}=10.0, p<0.01\right.$; Figure 1b) although with different efficacy. Thus, whereas TTX completely abolished the increase in 5-HT elicited by $1 \mathrm{mg} / \mathrm{kg}$ MK-801, it reduced glutamate levels to $40 \%$ of those induced by MK-801, as calculated using AUC from time $=0$ to time $=4 \mathrm{~h}(t=3.1, p<0.01$; Student's $t$-test, two-tailed $)$. When perfused alone, TTX also abolished basal dialysate 5-HT $\left(\mathrm{F}_{1,10}=95.5, p<0.00001\right.$; Figure 1a), whereas it was without effect on basal dialysate glutamate (Figure $1 \mathrm{~b}$ ).

\section{Effects of Systemic Administration of Antipsychotic Drugs}

The administration of haloperidol ( $1 \mathrm{mg} / \mathrm{kg}$, s.c.) failed to block the increase in 5-HT elicited by MK-801 (Figure 2a), but effectively blocked that of glutamate (Figure $2 \mathrm{~b}$ ) as demonstrated by the significant effect of treatment $\left(\mathrm{F}_{3,20}=\right.$ $12.5, p<0.0001)$, time $\left(\mathrm{F}_{15,300}=4.7, p<0.00001\right)$, and treatment $\times$ time interaction $\left(\mathrm{F}_{45,300}=3.7, p<0.00001\right)$. On the other hand, clozapine $(1-5 \mathrm{mg} / \mathrm{kg}$, s.c.) reduced $\mathrm{MK}-$ 801-induced increase in dialysate 5-HT in a dose-dependent manner (Figure 3a), as demonstrated by the significant effect of treatment $\left(\mathrm{F}_{3,24}=7.3, p<0.002\right)$, time $\left(\mathrm{F}_{15,360}=7.3\right.$, $p<0.00001)$, and the interaction between both factors $\left(\mathrm{F}_{45,360}=4.2, p<0.00001\right)$. Clozapine $(1-5 \mathrm{mg} / \mathrm{kg}$, s.c. $)$ also decreased MK-801-induced increase in dialysate glutamate in a dose-dependent manner (Figure 3b), as demonstrated by the significant effect of treatment $\left(\mathrm{F}_{3,19}=9.4, p<0.001\right)$, time $\left(\mathrm{F}_{15,285}=8.0, \quad p<0.000001\right)$, and treatment $\times$ time interaction $\left(F_{45,285}=3.2, p<0.000001\right)$. The effects of systemic clozapine were significant only at the dose of $5 \mathrm{mg} / \mathrm{kg}(p<0.05$ for 5 -HT and $p<0.005$ for glutamate; Newman-Keuls test), although the effect of the lowest dose almost reached significance for glutamate ( $p=0.051$; Newman-Keuls test). When administered alone, haloperidol 

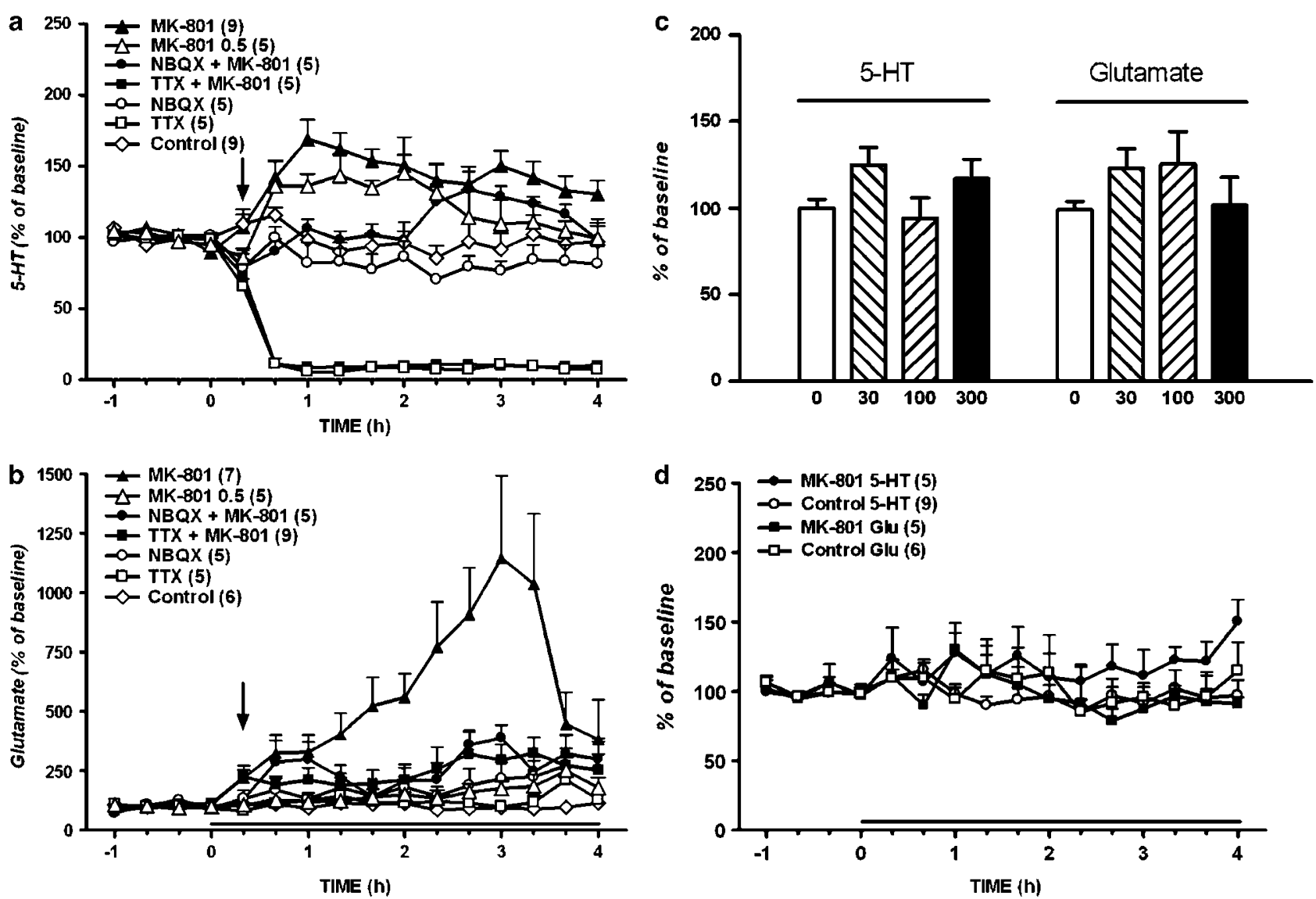

Figure I Effects of MK-80 I (0.5 and I mg/kg, i.p.) and of the local perfusion of NBQX (300 $\mu \mathrm{M})$ and TTX (I $\mu \mathrm{M})$ on the MK-80 I (I mg/kg, i.p.)-induced efflux of 5-HT (a) and glutamate (b) in the mPFC. Data (mean \pm SEM) are expressed as percentage changes of the four basal predrug values. Number of animals is given in parentheses. NBQX or TTX was perfused from time 0 to time $4 \mathrm{~h}$ (line). The effects of the local perfusion for 80 min of three different concentrations of MK-80 In the MPFC on dialysate 5-HT and glutamate are depicted in (c). Data in (c) are expressed as percentage of AUC calculated from four consecutive samples of $4(5-\mathrm{HT})$ and 5 animals (glutamate). The effects of the local perfusion of $300 \mu \mathrm{M}$ MK-80 I for $4 \mathrm{~h}$ in the mPFC on dialysate 5 -HT and glutamate (Glu) are depicted in (d).

( $1 \mathrm{mg} / \mathrm{kg}$, s.c.; Figure 2) and clozapine $(1-5 \mathrm{mg} / \mathrm{kg}$, s.c.; Figure 3 ) failed to alter dialysate 5 -HT or glutamate.

\section{Effects of Local Application of Antipsychotic Drugs in the MPFC}

The intra-mPFC perfusion of haloperidol $(3,30 \mu \mathrm{M})$ failed to modify the MK-801-induced increase in dialysate 5-HT (Figure 4a). However, the same concentrations of haloperidol suppressed the MK-801-induced increase in glutamate in a concentration-dependent manner (Figure $4 \mathrm{~b}$ ), as demonstrated by the significant effect of treatment $\left(\mathrm{F}_{2,19}=13.2\right.$, $p<0.001)$, time $\left(\mathrm{F}_{15,285}=11.0, p<0.00001\right)$, and the interaction between both factors $\left(\mathrm{F}_{30,285}=5.5, p<0.00001\right)$. Post hoc comparisons showed that only $30 \mu \mathrm{M}$ haloperidol significantly blocked the effects of MK-801 on glutamate $(p<0.001$; Newman-Keuls test). Intra-mPFC perfusion of clozapine $(30,100$, and $300 \mu \mathrm{M})$ reduced MK-801-evoked increase in dialysate 5-HT in a concentration-dependent manner (Figure $5 \mathrm{a}$ ), as demonstrated by the significant effect of treatment $\left(\mathrm{F}_{4,33}=7.0, p<0.0005\right)$, time $\left(\mathrm{F}_{15,495}=\right.$ 15.9, $p<0.00001)$, and treatment $\times$ time interaction $\left(\mathrm{F}_{60,495}=4.3, p<0.00001\right)$. Post hoc comparisons showed that only $300 \mu \mathrm{M}$ clozapine produced a significant effect $(p<0.05 ;$ Newman-Keuls test). In contrast, the three concentrations of clozapine were equipotent in blocking the MK-801-induced increase in glutamate (Figure 5b), as demonstrated by the significant effect of treatment $\left(\mathrm{F}_{4,29}=12.7, p<0.00001\right)$, time $\left(\mathrm{F}_{15,435}=7.0, p<0.000001\right)$, and their interaction $\left(\mathrm{F}_{60,435}=4.9, p<0.000001\right)$.

When perfused alone, haloperidol ( 3 and $30 \mu \mathrm{M}$ ) had no effect on dialysate 5-HT (Figure 6a) and glutamate (Figure 6b). Intra-mPFC perfusion of clozapine $(30,100$, and $300 \mu \mathrm{M}$ ) decreased dialysate 5-HT in a concentrationdependent manner (Figure 7a), as demonstrated by the significant effect of treatment $\left(\mathrm{F}_{3,21}=3.7, p<0.03\right)$, time $\left(\mathrm{F}_{15,315}=2.3, \quad p<0.005\right)$, and the interaction between both factors $\left(\mathrm{F}_{45,315}=1.6, p<0.02\right)$. Clozapine had also a significant effect on dialysate glutamate (Figure $7 \mathrm{~b}$ ), as demonstrated by the significant effect of treatment $\left(\mathrm{F}_{3,20}=\right.$ 3.3, $p<0.05)$, time $\left(\mathrm{F}_{15,300}=2.3, p<0.005\right)$, and the interaction of both factors $\left(\mathrm{F}_{45,300}=1.7, p<0.01\right)$. Post hoc comparisons showed that only $300 \mu \mathrm{M}$ clozapine increased significantly the concentration of glutamate $(p<0.05$; Newman-Keuls test).

\section{DISCUSSION}

The first finding of the present study is that systemic administration of the NMDA receptor antagonist, MK-801, 

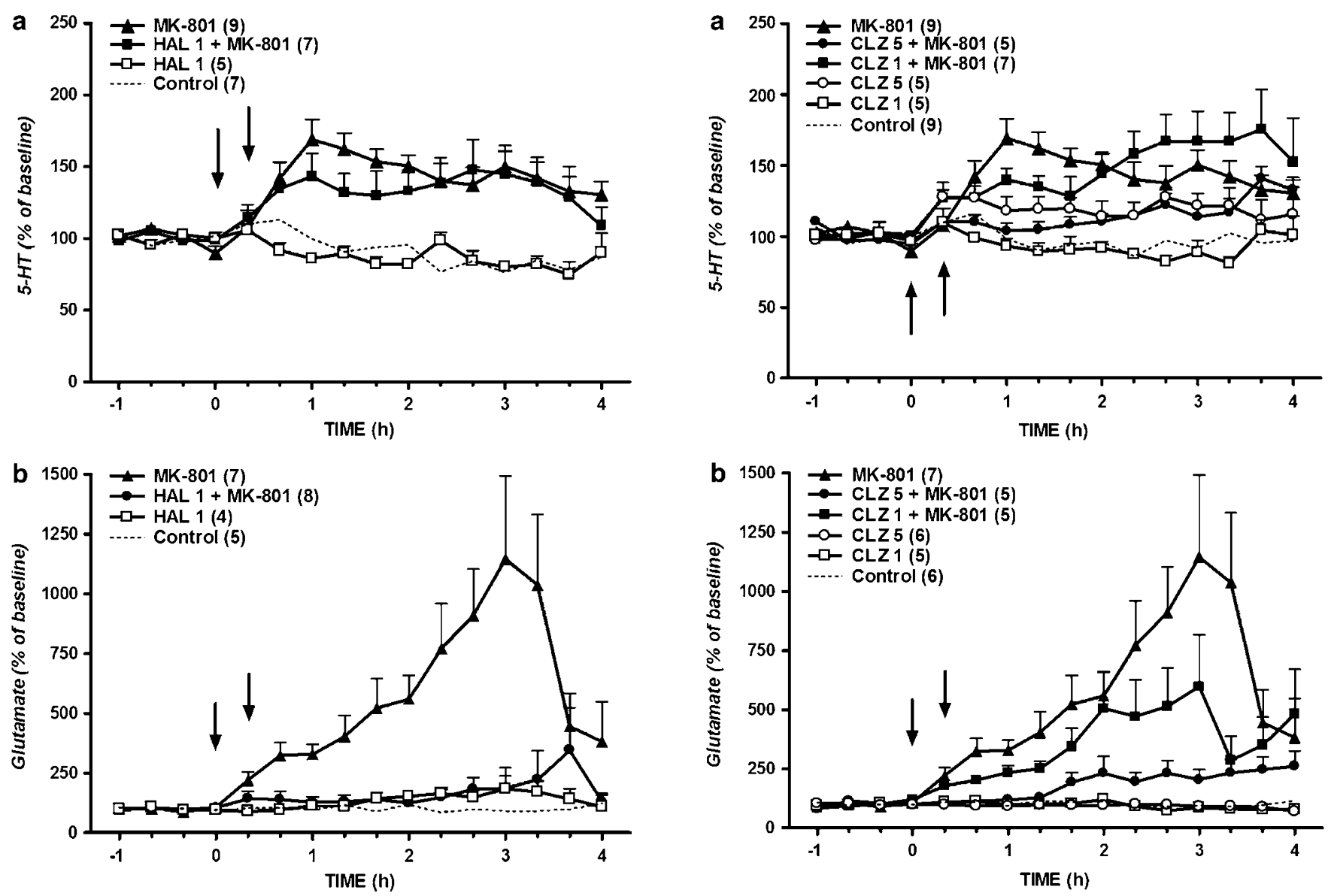

Figure 2 Effects of pretreatment (first arrow) with haloperidol (I mg/kg, s.c.; HAL I) on the efflux of 5-HT (a) and glutamate (b) in the mPFC elicited by MK-80 I (I mg/kg, i.p.; second arrow). Data (mean \pm SEM) are expressed as percentage changes of the four basal predrug values. Number of animals is given in parentheses. The control group received two injections (saline and vehicle) and, for the sake of clarity, is depicted as a dotted line.

enhanced the extracellular concentration of 5-HT and glutamate in the mPFC. This was previously shown for PCP (Adams and Moghadam, 2001). The kinetics of MK801-induced changes in glutamate strongly paralleled those of induction of cortical c-fos mRNA, which also peaked at 3-4h after the administration of MK-801 (Väisänen et al, 1999). This coincidence suggests that induction of c-fos mRNA synthesis would likely result from increased cortical glutamate efflux. These increases in 5-HT and glutamate are dependent on nerve impulse because they were inhibited by TTX, although to a different extent. Thus, basal and MK-801-induced elevation of 5-HT were both completely dependent on nerve impulse. However, basal dialysate glutamate in the MPFC was not blocked by TTX, in good agreement with prior work (Moghaddam, 1993; Timmerman et al, 1999), which pointed out that only a minor portion of basal extracellular glutamate is indeed exocytotically released (Timmerman and Westerink, 1997).

Nevertheless, the present study evidenced that MK-801stimulated glutamate efflux is largely TTX dependent, that is released from neurons in an impulse-dependent manner. This is in line with previous work showing that the efflux of glutamate elicited by ketamine was also fully dependent on

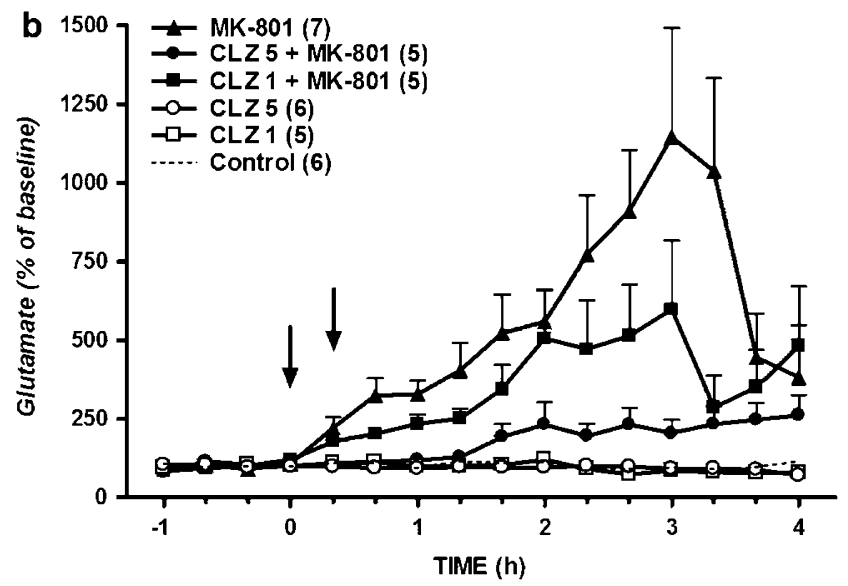

Figure 3 Effects of pretreatment (first arrow) with clozapine (I or $5 \mathrm{mg} /$ kg, s.c.; CLZ I or CLZ 5) on the efflux of 5-HT (a) and glutamate (b) in the mPFC elicited by MK-80 I ( I mg/kg, i.p.; second arrow). Data (mean \pm SEM) are expressed as percentage changes of the four basal predrug values. Number of animals is given in parentheses. The control group received two injections (saline and vehicle) and, for the sake of clarity, is depicted as a dotted line.

nerve impulse (Lorrain et al, 2003). It remains to be determined, however, the provenance of NMDA receptor antagonist-stimulated extracellular glutamate in the mPFC. The fact that local perfusion of PCP, ketamine, and MK-801 in the $\mathrm{MPFC}$ failed to elicit the increase in glutamate and/or 5-HT (Lorrain et al, 2003; Amargós-Bosch et al, 2006, this study) indicates that the NMDA receptors responsible for these effects are located outside the mPFC. Our results are consistent with other data showing that the increased locomotion and firing or EPSCs of putative pyramidal neurons of the MPFC following systemic administration of NMDA receptor antagonists (Suzuki et al, 2002; Jodo et al, 2003; Jackson et al, 2004) were not mimicked by intra-mPFC application of these compounds (Aghajanian and Marek, 2000; Suzuki et al, 2002; Jodo et al, 2005). What is the actual localization of these NMDA receptors and the source of the cortical hyperglutamatergic transmission induced by their blockade? Two of the well-known ascending glutamatergic inputs to the mPFC arise from the hippocampus (Carr and Sesack, 1996; Dégenètais et al, 2003) and the mediodorsal nucleus of the thalamus (Kuroda et al, 1998), and in both areas glutamatergic neurons are under the control of GABAergic cells (Gigg et al, 1994; 

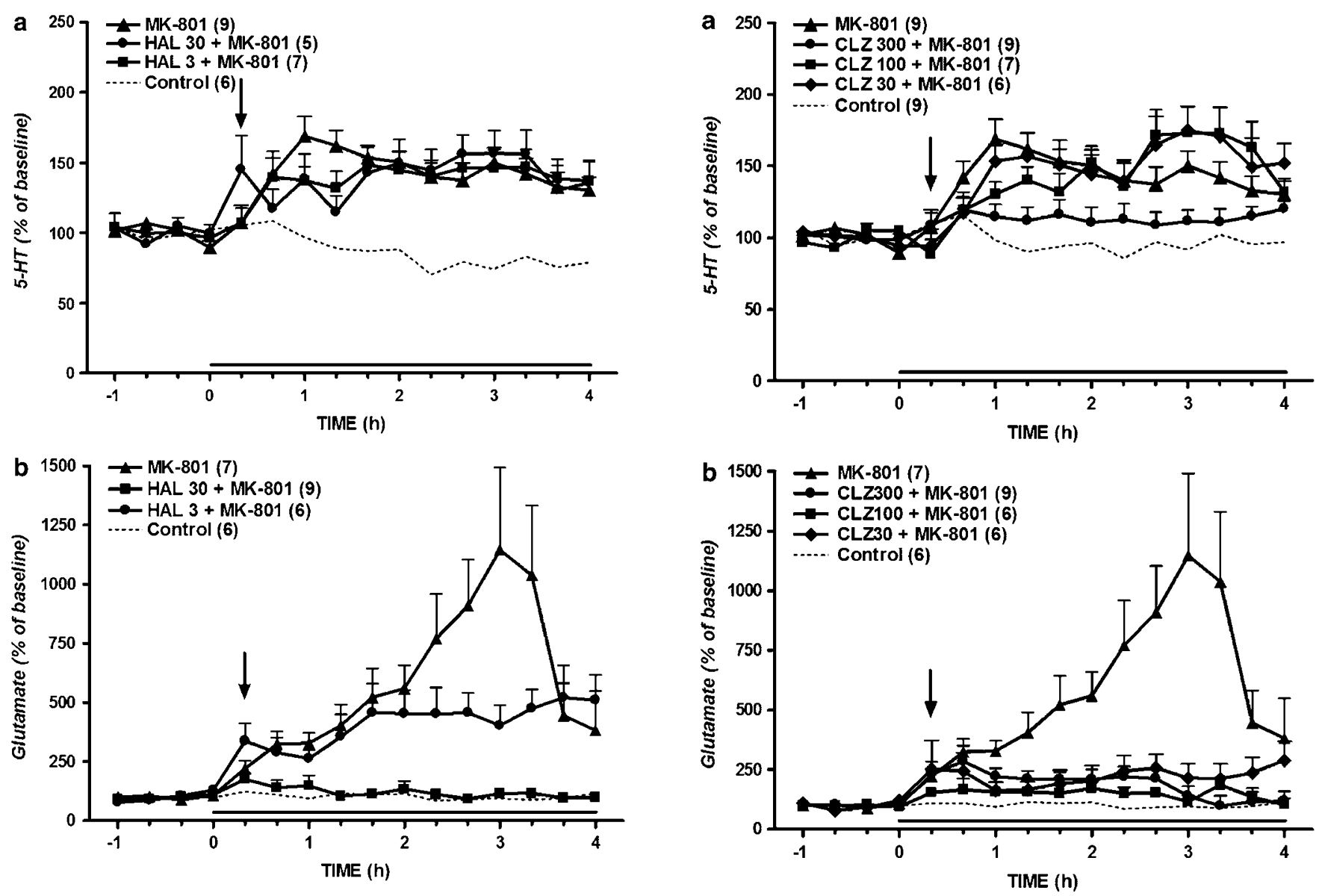

Figure 4 Effects of the intra-mPFC perfusion (line) of haloperidol (3 and $30 \mu \mathrm{M}$; HAL 3 and HAL 30, respectively) on the efflux of 5-HT (a) and glutamate (b) in the MPFC elicited by MK-80 I (I mg/kg, i.p.; arrow). Data (mean \pm SEM) are expressed as percentage changes of the four basal predrug values. Number of animals is given in parentheses. The control group received an injection of saline and, for the sake of clarity, is depicted as a dotted line.

Krimer and Goldman-Rakic, 2001). In accordance with these findings, it has been shown that the local application of PCP into the hippocampus increases locomotion and the firing of pyramidal neurons of the mPFC in freely moving rats (Jodo et al, 2005). Furthermore, Sharp and coworkers have described that the blockade of NMDA receptors in the anterior thalamus by MK-801 resulted in injury of cortical pyramidal neurons measured by an increased synthesis of heat-shock protein 70 (HSP-70) in limbic cortex (Tomitaka et al, 2000; Sharp et al, 2001). Thus, all these findings suggest that NMDA receptor antagonists would attenuate the tonic activation of inhibitory (GABA) neurons (possibly, though not exclusively, in the hippocampus and/or the thalamus), which would result in a disinhibition of glutamatergic input to the mPFC (Olney and Farber, 1995; Moghaddam et al, 1997; Krystal et al, 2003). In fact, GABAergic neurons are very sensitive to NMDA antagonism (Grunze et al, 1996; Li et al, 2002), and PCP and MK-801 are able to reduce dialysate GABA in the mPFC (Yonezawa et al, 1998) and striatum (Hondo et al, 1995). Our results would suggest that the GABAergic control of glutamate efflux within the mPFC would not have a tonic nature.

Figure 5 Effects of the intra-mPFC perfusion (line) of clozapine (30, 100 and $300 \mu \mathrm{M} ; \mathrm{CLZ} 30, \mathrm{CLZ}$ I00, and CLZ 300, respectively) on the efflux of 5-HT (a) and glutamate (b) in the mPFC elicited by MK-80 I ( I mg/kg, i.p.; arrow). Data (mean \pm SEM) are expressed as percentage changes of the four basal predrug values. Number of animals is given in parentheses. The control group received an injection of saline and, for the sake of clarity, is depicted as a dotted line.

On the other hand, the increased extracellular concentrations of 5-HT and glutamate elicited by MK-801 are mediated by a stimulation of cortical AMPA receptors because they were suppressed by intra-mPFC perfusion of NBQX. Consistent with our findings, it has been shown that blockade of AMPA/kainate receptors in the prefrontal cortex inhibited PCP-induced locomotion and stereotypy (Takahata and Moghaddam, 2003). Thus, in line with previous reports (Moghaddam et al, 1997; Adams and Moghadam, 2001; Lorrain et al, 2003), MK-801 increases glutamate release onto AMPA/kainate receptors, which, in turn, elicit an enhanced glutamatergic output from mPFC neurons, including those projecting to the dorsal raphe nucleus, thereby increasing serotonergic cell firing and cortical 5-HT efflux. Although this functional interplay between the mPFC and the dorsal raphe nucleus is well documented (Hajós et al, 1998; Celada et al, 2001; MartínRuiz et al, 2001; Amargós-Bosch et al, 2003; Lucas et al, 2005), we presently cannot rule out the possibility of a direct effect of MK-801 on serotonergic neurons of the dorsal raphe nucleus (Callado et al, 2000; Tao and Auerbach, 2000) and its blockade downstream by NBQX acting on AMPA receptors putatively located in serotonergic terminals 

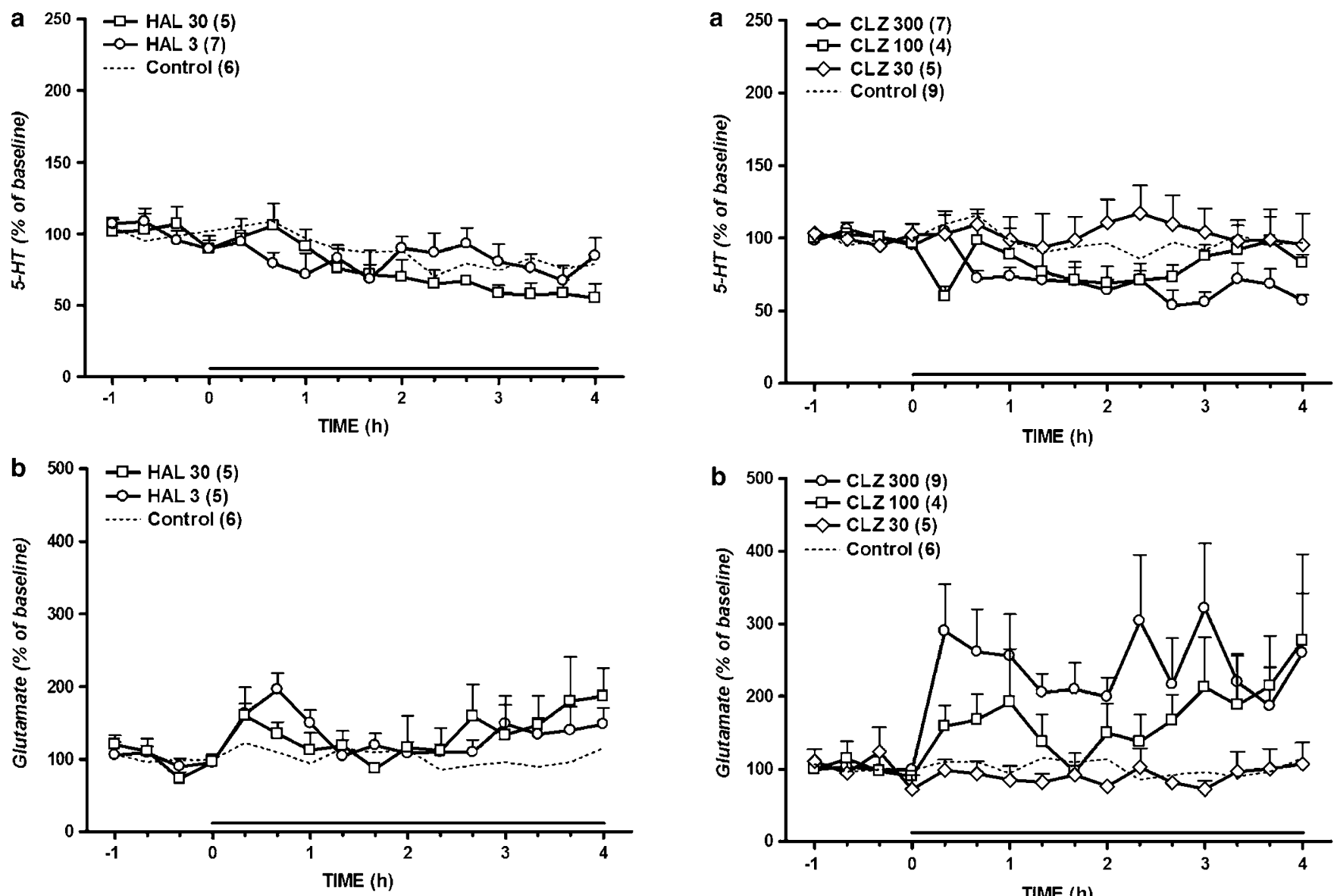

Figure 6 Effects of the local perfusion of haloperidol (3 and $30 \mu \mathrm{M}$; HAL 3 and HAL 30, respectively) on the efflux of 5-HT (a) and glutamate (b) in the $\mathrm{mPFC}$. Data (mean \pm SEM) are expressed as percentage changes of the four basal predrug values. Number of animals is given in parentheses.

(Maione et al, 1997). With regard to glutamate, however, although presynaptic AMPA receptors have been described in striatal glutamatergic axon terminals (Patel et al, 2001; Fujiyama et al, 2004), they do not seem to be present in the cortical counterparts (Fujiyama et al, 2004). Interestingly, the effect of NBQX on MK-801-induced increase in 5 -HT appeared to be biphasic. Thus, NBQX was able to completely prevent the effect of MK-801 on 5-HT in the first phase $(0-2 \mathrm{~h})$, but not in the second $(2-4 \mathrm{~h})$. Although further research is warranted to know the mechanisms underlying these effects, it is possible that the late increase in cortical serotonergic transmission may result from a direct stimulation of 5-HT cells within the dorsal raphe nucleus by MK-801 (Callado et al, 2000; Tao and Auerbach, 2000 ), or from the activation of a different brain circuitry not including the mPFC (for instance hippocampus $\rightarrow$ amygdala $\rightarrow$ raphe).

Taken together that the effects of MK-801 mostly depends on glutamatergic projections from regions outside the MPFC, and that AMPA/kainate receptors are located predominantly in pyramidal cells, it was expected that NBQX would have blocked the MK-801-induced increase in $5-\mathrm{HT}$, but not that of glutamate. Unexpectedly, however, NBQX was able to block both actions of MK-801. It is conceivable that MK-801 could have elicited an initial subtle

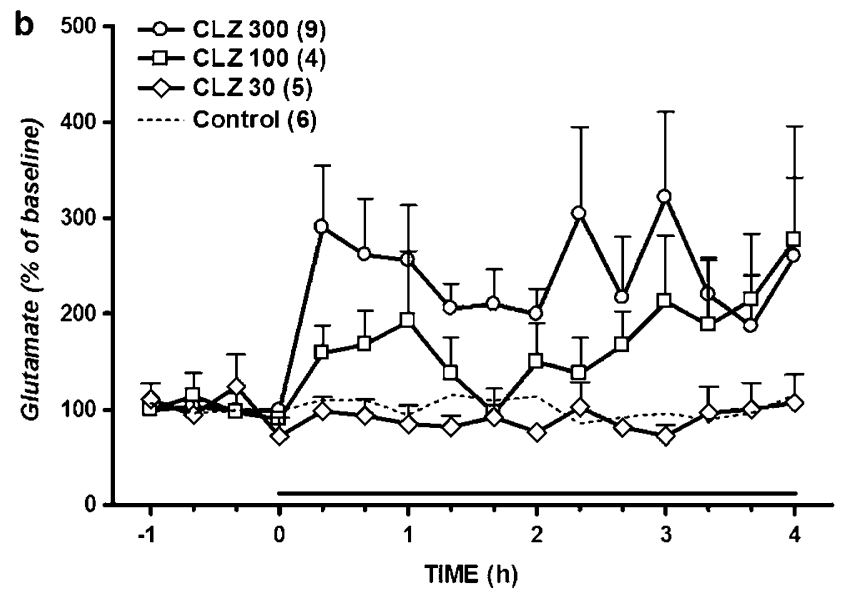

Figure 7 Effects of the local perfusion of clozapine (30, 100, and $300 \mu \mathrm{M}$; CLZ 30, CLZ 100, and CLZ 300, respectively) on the efflux of 5-HT (a) and glutamate $(b)$ in the mPFC. Data (mean \pm SEM) are expressed as percentage changes of the four basal predrug values. Number of animals is given in parentheses.

(not measurable in the present conditions) increase in glutamate from external sources. This glutamate could have been able to stimulate pyramidal cells immediately and the subsequent increase in glutamate measured would have resulted from a cascade of excitation within pyramidal cells, instead of directly from an external glutamatergic input. This proposal is consistent with our finding that a lower dose of $\mathrm{MK}-801(0.5 \mathrm{mg} / \mathrm{kg})$ was able to increase $5-\mathrm{HT}$ without altering cortical glutamate. Therefore, the present results imply that the stimulation of cortical AMPA/kainate receptors can be achieved by subtle changes in glutamate level, which cannot be detected in the experimental conditions used because the stimulation of subcortical glutamatergic afferents immediately leads to the activation of pyramidal neurons. Overall, our results suggest that extracellular glutamate measured after MK-801 administration would partly arise from $\mathrm{MPFC}$ or at least depend on activation of mPFC output.

The second main finding of the present study is that clozapine and haloperidol differently blocked the MK-801induced increase in 5-HT and glutamate. Thus, in line with our previous work with PCP and ketamine (Amargós-Bosch et al, 2006), the systemic administration of clozapine suppressed the increase of serotonin in the mPFC, whereas 
haloperidol did not. The fact that a higher dose of clozapine $(5 \mathrm{mg} / \mathrm{kg})$ was needed to block the effects of MK-801 in comparison with those of PCP and ketamine (AmargósBosch et al, 2006) could be related to the higher potency of MK-801 in binding to the NMDA receptor channel. In contrast, systemic haloperidol completely abolished the MK-801-induced increase in glutamate. In a previous study, Adams and Moghadam (2001) showed that clozapine $(10 \mathrm{mg} / \mathrm{kg})$ and haloperidol $(0.1 \mathrm{mg} / \mathrm{kg})$ failed to block the increase in dialysate glutamate elicited by PCP. However, in this study clozapine was administered i.p., which presumably result in a lower brain concentration of the drug, possibly insufficient to block the effect of PCP. On the other hand, it is possible that the blocking actions of clozapine on glutamate would be more prominent when the stimulated efflux is higher, which is the case of MK-801 (this study) compared to PCP (Adams and Moghadam, 2001). In fact, both clozapine and haloperidol are able to block the effect of MK-801 on extracellular glutamate. In line with this, Homayoun and Moghaddam (2007) have recently shown that clozapine and haloperidol share the ability to markedly inhibit a small subset of mPFC neurons. Furthermore, only around 5\% of projection neurons in the V layer of the mPFC project to the dorsal raphe nucleus, according to Gabbott et al. (2005). Thus, it is conceivable that under the conditions of the present study (increased 5-HT and glutamate transmission in the $\mathrm{mPFC}$ ) haloperidol may be able to inhibit a subpopulation of pyramidal cells (blockade of increased glutamate efflux), though sparing cortico-raphe projections. Alternatively, it could be also possible that cortico-raphe projecting cells might be inhibited by haloperidol, but not to the extent needed to suppress serotonergic firing distally in the dorsal raphe nucleus and subsequent cortical 5-HT release. Differences in the receptor population present in pyramidal cells and the distinct pharmacological profile of clozapine, acting on different transmitter receptors particularly abundant in layer $\mathrm{V} \mathrm{mPFC}$ neurons, could provide the anatomical substrate for this differential effect. It thus appears that serotonergic transmission in the mPFC is regulated by the concurrent participation of multiple transmitter receptors, whereas glutamatergic transmission is strongly dependent on dopamine D2 receptor activation. Further evidence of the regulation of glutamate release in the MPFC by dopamine D2 receptors is provided by electrophysiological studies. Thus, the augmented efflux of dopamine elicited by the blockade of NMDA receptors (Moghaddam and Adams, 1998; Mathé et al, 1999; Schmidt and Fadayel, 1996) may promote dopamine D2-induced burst firing only in a small subset of pyramidal cells of the mPFC (Wang and Goldman-Rakic, 2004), possibly in those cells enriched in dopamine D2 receptors. In summary, it appears that dopamine D2 antagonism in the MPFC may be pathway specific, affecting only a reduced number of pyramidal cells (Wang and Goldman-Rakic, 2004). In line with our results, both clozapine and haloperidol inhibit MK-801-induced induction of cortical c-fos mRNA (Väisänen et al, 1999), which further suggests that this effect may result from blockade of glutamate efflux. When administered alone, neither clozapine nor haloperidol, given systemically, altered the concentrations of 5-HT and glutamate, which is consistent with previous results (Daly and Moghaddam,
1993; Yamamoto et al, 1994; Cartmell et al, 2001; Heidbreder et al, 2001). Although recent data from our lab showed that the dose of $1 \mathrm{mg} / \mathrm{kg}$ of both antipsychotics elicited a maximal reduction of dialysate $5-\mathrm{HT}$ in the $\mathrm{mPFC}$ to $\sim 70 \%$ of basal values (Amargós-Bosch et al, 2006), such weak effect was comparable to that reported herein ( $\sim 80 \%)$. The ability of clozapine to attenuate MK-801evoked change in cortical 5-HT may be related to its superior effects in negative/cognitive symptoms. Actually, clozapine but not haloperidol effectively blocks the hyperactivity, metabolic activation, neurotoxic cell damage, as well as the deficits in prepulse inhibition and social interaction induced by NMDA receptor antagonists (Corbett et al, 1995; Gleason and Shannon, 1997; Abi-Saab et al, 1998; Duncan et al, 1998; Olney et al, 1999; Geyer et al, 2001; Farber et al, 2006). Further research is needed to ascertain the transmitter receptors responsible for such differences between clozapine and haloperidol.

In good accordance with the effects of systemic administration, the intra-mPFC perfusion of clozapine was able to block the increases of both 5-HT and glutamate evoked by MK-801, whereas haloperidol was only effective in blocking the increased efflux of glutamate. To the best of our knowledge, this is the first report that shows the effects of antipsychotic drugs applied locally into the $\mathrm{mPFC}$ on the neurochemical changes elicited by the systemic administration of noncompetitive NMDA receptor antagonists. The intra-mPFC action of clozapine and haloperidol paralleled those of their systemic administration, which underscores the important role of the mPFC in the pharmacological effects of these antipsychotic drugs. This was not unexpected given that the prefrontal cortex is involved in goaldirected actions, such as working memory and cognitive tasks (Goldman-Rakic, 1995; Ellenbroek et al, 1996; Carli et al, 2006), and these functions are disrupted after NMDA receptor antagonism (Abi-Saab et al, 1998; Olney et al, 1999; Geyer et al, 2001; Jackson et al, 2004) and in schizophrenia (Weinberger and Gallhofer, 1997; Park et al, 1999). The mechanisms underlying these differential effects of clozapine and haloperidol remain unknown, but might be the basis of their differential effectiveness on negative/cognitive symptoms (Lieberman, 1996). The finding that clozapine produces opposite effects on glutamatergic transmission depending on the activity of mPFC neurons is not new. In fact, clozapine has been shown to increase the activity of neurons with low baseline firing rates and reduce that of neurons with higher firing rates (Homayoun and Moghaddam, 2007). It is, thus, possible that the local reduction of 5$\mathrm{HT}$ in the mPFC may be mediated through the action of clozapine on a multiplicity of receptors, such as dopamine $\mathrm{D} 1,5-\mathrm{HT}_{2 \mathrm{~A}}, 5-\mathrm{HT}_{2 \mathrm{C}}, \alpha$-adrenergic, histamine $\mathrm{H} 1$, and/or muscarinic M1 receptors (Bymaster et al, 1996; Arnt and Skarsfeldt, 1998). On the other hand, the clozapine-induced increase in glutamate efflux (albeit only at high concentration) has been postulated to result from its potentiation of NMDA transmission through an inhibition of glycine reuptake and/or a direct agonist action on the glycine recognition site of NMDA receptors (see Millan, 2005 for review). Alternatively, extracellular concentration of glutamate may also be secondary to inhibition of GABA efflux elicited by clozapine (Bourdelais and Deutch, 1994). Altogether, these findings suggest that abnormally high 
glutamate levels in the mPFC (caused by a primary NMDA receptor hypofunction) may be related, at least in part, with some of the psychotic/positive symptoms of schizophrenia that are generally alleviated by all antipsychotics, probably through a blockade of dopamine D2 receptors (Coyle and Tsai, 2004). In contrast, a disruption of 5-HT in the mPFC could rather be associated to negative symptoms and/or cognitive impairment, conditions for which clozapine depicts a superior efficacy. Although further research is needed to verify this hypothesis, it is interesting to note that some of the atypical antipsychotic drugs (characterized by their antiserotonergic properties together with a relatively weaker dopamine D2 antagonism) have been reported to display a better outcome in the control of negative symptoms compared with typical antipsychotics (Meltzer, 1999).

In summary, the results of the present study indicate that MK-801 (and possibly other noncompetitive NMDA receptor antagonists) increases the efflux of glutamate and 5 -HT in the mPFC through the blockade of NMDA receptors located outside the $\mathrm{mPFC}$ (or at least, outside the area sampled by dialysis probes), and the activation of AMPA receptors present in the mPFC. The local effects of clozapine and haloperidol paralleled those observed after systemic administration, which emphasizes the relevance of the MPFC as a site of action of these antipsychotic drugs in offsetting the neurochemical effects of MK-801. Both clozapine and haloperidol blocked the effects of MK-801 on cortical glutamate, but only clozapine showed a unique ability in suppressing an excessive serotonergic activity in the mPFC. Although this latter action is shared by olanzapine (Amargós-Bosch et al, 2006), further research is needed to determine whether this is a distinct feature of atypicality of antipsychotic drugs.

\section{ACKNOWLEDGEMENTS}

This work was supported by the Spanish Ministry of Education and Science Grants SAF 2004-05525 and SAF 2003-04930 and by the Generalitat de Catalunya (SGR2005/ 00758 and SGR2005/00826). XL-G, ZB, and MA-B were recipients of predoctoral fellowships from the Consejo Superior de Investigaciones Científicas (CSIC), Spanish Ministry of Education and Science, and Institut d'Investigacions Biomèdiques August Pi i Sunyer (IDIBAPS), respectively. We gratefully acknowledge the skillful technical assistance of Leticia Campa and Judith Ballart.

\section{DISCLOSURE/CONFLICT OF INTEREST}

The authors declare that they have no competing financial interests.

\section{REFERENCES}

Abi-Saab W, D'Souza DC, Moghaddam B, Krystal JH (1998). The NMDA antagonist model for schizophrenia: promises and pitfalls. Pharmacopsychiatry 31: 104-109.

Adams BW, Moghadam B (2001). Effect of clozapine, haloperidol, or M100907 on phencyclidine-activated glutamate efflux in the prefrontal cortex. Biol Psychiatry 50: 750-757.
Adell A, Artigas F (1998). A microdialysis study of the in vivo release of 5-HT in the median raphe nucleus of the rat. $\mathrm{Br} J$ Pharmacol 125: 1361-1367.

Adell A, Celada P, Abellán MT, Artigas F (2002). Origin and functional role of the extracellular serotonin in the midbrain raphe nuclei. Brain Res Rev 39: 154-180.

Aghajanian GK, Marek GJ (2000). Serotonin model of schizophrenia: emerging role of glutamate mechanisms. Brain Res Rev 31: 302-312.

Amargós-Bosch M, Adell A, Bortolozzi A, Artigas F (2003). Stimulation of $\alpha_{1}$-adrenoceptors in the rat medial prefrontal cortex increases the local in vivo 5-hydroxytryptamine release: reversal by antipsychotic drugs. J Neurochem 87: 831-842.

Amargós-Bosch M, López-Gil X, Artigas F, Adell A (2006). Clozapine and olanzapine, but not haloperidol, suppress serotonin efflux in the medial prefrontal cortex elicited by phencyclidine and ketamine. Int J Neuropsychopharmacol 9: 565-573.

Arnt J, Skarsfeldt T (1998). Do novel antipsychotics have similar pharmacological characteristics? A review of the evidence. Neuropsychopharmacology 18: 63-101.

Babot Z, Cristòfol R, Suñol C (2005). Excitotoxic death induced by released glutamate in depolarized primary cultures of mouse cerebellar granule cells is dependent on $\mathrm{GABA}_{\mathrm{A}}$ receptors and niflumic acid-sensitive chloride channels. Eur J Neurosci 21: 103-112.

Bakshi VP, Swerdlow NR, Geyer MA (1994). Clozapine antagonizes phencyclidine-induced deficits in sensorimotor gating of the startle response. J Pharmacol Exp Ther 271: 787-794.

Bourdelais AJ, Deutch AY (1994). The effects of haloperidol and clozapine on extracellular GABA levels in the prefrontal cortex of the rat: an in vivo microdialysis study. Cereb Cortex 4: 69-77.

Bymaster FP, Calligaro DO, Falcone JF, Marsh RD, Moore NA, Tye NC et al (1996). Radioreceptor binding profile of the atypical antipsychotic olanzapine. Neuropsychopharmacology 14: $87-96$.

Callado LF, Hopwood SE, Hancock PJ, Stamford JA (2000). Effects of dizocilpine (MK 801) on noradrenaline, serotonin and dopamine release and uptake. Neuroreport 11: 173-176.

Carli M, Baviera M, Invernizzi RW, Balducci C (2006). Dissociable contribution of $5-\mathrm{HT}_{1 \mathrm{~A}}$ and $5-\mathrm{HT}_{2 \mathrm{~A}}$ receptors in the medial prefrontal cortex to different aspects of executive control such as impulsivity and compulsive perseveration in rats. Neuropsychopharmacology 31: 757-767.

Carr DB, Sesack SR (1996). Hippocampal afferents to the rat prefrontal cortex: synaptic targets and relation to dopamine terminals. J Comp Neurol 369: 1-15.

Cartmell J, Perry KW, Salhoff CR, Monn JA, Schoepp DD (2001). Acute increases in monoamine release in the rat prefrontal cortex by the mGlu2/3 agonist LY379268 are similar in profile to risperidone, not locally mediated, and can be elicited in the presence of uptake blockade. Neuropharmacology 40: 847-855.

Celada P, Puig MV, Casanovas JM, Guillazo G, Artigas F (2001). Control of dorsal raphe serotonergic neurons by the medial prefrontal cortex: involvement of serotonin-1A, $\mathrm{GABA}_{\mathrm{A}}$, and glutamate receptors. J Neurosci 21: 9917-9929.

Corbett R, Camacho F, Woods AT, Kerman LL, Fishkin RJ, Brooks $\mathrm{K}$ et al (1995). Antipsychotic agents antagonize non-competitive $\mathrm{N}$-methyl-D-aspartate antagonist-induced behaviors. Psychopharmacology 120: 67-74.

Coyle JT, Tsai G (2004). The NMDA receptor glycine modulatory site: a therapeutic target for improving cognition and reducing negative symptoms in schizophrenia. Psychopharmacology 174: $32-38$.

Daly DA, Moghaddam B (1993). Actions of clozapine and haloperidol on the extracellular levels of excitatory amino acids in the prefrontal cortex and striatum of conscious rats. Neurosci Lett 152: 61-64. 
Dégenètais E, Thierry A-M, Glowinski J, Gioanni Y (2003). Synaptic influence of hippocampus on pyramidal cells of the rat prefrontal cortex: an in vivo intracellular recording study. Cereb Cortex 13: 782-792.

Duncan GE, Leipzig JN, Mailman RB, Lieberman JA (1998). Differential effects of clozapine and haloperidol on ketamineinduced metabolic activation. Brain Res 812: 65-75.

Ellenbroek BA, Budde S, Cools AR (1996). Prepulse inhibition and latent inhibition: the role of dopamine in the medial prefrontal cortex. Neuroscience 75: 535-542.

Farber NB, Nemmers B, Noguchi KK (2006). Acute $D_{2} / D_{3}$ dopaminergic agonism but chronic $\mathrm{D}_{2} / \mathrm{D}_{3}$ antagonism prevents NMDA antagonist neurotoxicity. Biol Psychiatry 60: 630-638.

Fujiyama F, Kuramoto E, Okamoto K, Hioki H, Furuta T, Zhou L et al (2004). Presynaptic localization of an AMPA-type glutamate receptor in corticostriatal and thalamostriatal axon terminals. Eur J Neurosci 20: 3322-3330.

Gabbott PLA, Warner TA, Jays PRL, Salway P, Busby SJ (2005). Prefrontal cortex in the rat: projections to subcortical autonomic, motor, and limbic centers. J Comp Neurol 492: 145-177.

Geyer MA, Krebs-Thomson K, Braff DL, Swerdlow NR (2001). Pharmacological studies of prepulse inhibition models of sensorimotor gating deficits in schizophrenia: a decade in review. Psychopharmacology 156: 117-154.

Gigg J, Tan AM, Finch DM (1994). Glutamatergic hippocampal formation projections to prefrontal cortex in the rat are regulated by GABAergic inhibition and show convergence with glutamatergic projections from the limbic thalamus. Hippocampus 4: 189-198.

Giros B, Jaber M, Jones SR, Wightman RM, Caron MG (1996). Hyperlocomotion and indifference to cocaine and amphetamine in mice lacking the dopamine transporter. Nature 379: 606-612.

Gleason SD, Shannon HE (1997). Blockade of phencyclidineinduced hyperlocomotion by olanzapine, clozapine and serotonin receptor subtype selective antagonists in mice. Psychopharmacology 129: 79-84.

Goldman-Rakic PS (1995). Cellular basis of working memory. Neuron 14: 477-485.

Grunze HCR, Rainnie DG, Hasselmo ME, Barkai E, Hearn EF, McCarley RW et al (1996). NMDA-dependent modulation of CA1 local circuit inhibition. J Neurosci 16: 2034-2043.

Hajós M, Richards CD, Székely AD, Sharp T (1998). An electrophysiological and neuroanatomical study of the medial prefrontal cortical projections to the midbrain raphe nuclei in the rat. Neuroscience 87: 95-108.

Heidbreder CA, Foxton R, Cilia J, Hughes ZA, Shah AJ, Atkins A et al (2001). Increased responsiveness of dopamine to atypical, but not typical antipsychotics in the medial prefrontal cortex of rats reared in isolation. Psychopharmacology 156: 338-351.

Hertel P, Mathé JM, Nomikos GG, Iurlo M, Mathé AA, Svensson TH (1996). Effects of D-amphetamine and phencyclidine on behavior and extracellular concentrations of neurotensin and dopamine in the ventral striatum and the medial prefrontal cortex of the rat. Behav Brain Res 72: 103-114.

Homayoun H, Moghaddam B (2007). Fine-tuning of awake prefrontal cortex neurons by clozapine: comparison with haloperidol N-desmethylclozapine. Biol Psychiatry 61: 679-687.

Homayoun H, Stefani MR, Adams BW, Tamagan GD, Moghaddam B (2004). Functional interaction between NMDA and mGlu5 receptors: effects on working memory, instrumental learning, motor behaviors, and dopamine release. Neuropsychopharmacology 29: 1259-1269.

Hondo H, Nakahara T, Nakamura K, Hirano M, Uchimura $H$, Tashiro N (1995). The effect of phencyclidine on the basal and high potassium evoked extracellular GABA levels in the striatum of freely-moving rats: an in vivo microdialysis study. Brain Res 671: $54-62$.
Iravani MM, Muscat R, Kruk ZL (1999). MK-801 interaction with the 5-HT transporter: a real-time study in brain slices using fast cyclic voltammetry. Synapse 32: 212-224.

Jackson ME, Homayoun H, Moghaddam B (2004). NMDA receptor hypofunction produces concomitant firing rate potentiation and burst activity reduction in the prefrontal cortex. Proc Natl Acad Sci USA 101: 8467-8472.

Javitt DC, Zukin SR (1991). Recent advances in the phencyclidine model of schizophrenia. Am J Psychiatry 148: 1301-1308.

Jentsch JD, Roth RH (1999). The neuropsychopharmacology of phencyclidine: from NMDA receptor hypofunction to the dopamine hypothesis of schizophrenia. Neuropsychopharmacology 20: 201-225.

Jentsch JD, Tran A, Taylor JR, Roth RH (1998). Prefrontal cortical involvement in phencyclidine-induced activation of the mesolimbic dopamine system: behavioral and neurochemical evidence. Psychopharmacology 138: 89-95.

Jodo E, Suzuki Y, Katayama T, Hoshino KY, Takeuchi S, Niwa SI et al (2005). Activation of medial prefrontal cortex by phencyclidine is mediated via a hippocampo-prefrontal pathway. Cereb Cortex 15: 663-669.

Jodo E, Suzuki Y, Takeuchi S, Niwa SI, Kayama Y (2003). Different effects of phencyclidine and methamphetamine on firing activity of medial prefrontal cortex neurons in freely moving rats. Brain Res 962: 226-231.

Krimer LS, Goldman-Rakic PS (2001). Prefrontal microcircuits: membrane properties and excitatory input of local, medium, and wide arbor interneurons. J Neurosci 21: 3788-3796.

Krystal JH, D'Souza DC, Mathalon D, Perry E, Belger A, Hoffman R (2003). NMDA receptor antagonist effects, cortical glutamatergic function, and schizophrenia: toward a paradigm shift in medication development. Psychopharmacology 169: 215-233.

Krystal JH, Karper LP, Seibyl JP, Freeman GK, Delaney R, Bremner JD et al (1994). Subanesthetic effects of the noncompetitive NMDA antagonist, ketamine, in humans. Psychotomimetic, perceptual, cognitive, and neuroendocrine responses. Arch Gen Psychiatry 51: 199-214.

Kuroda M, Yokofujita J, Murakami K (1998). An ultrastructural study of the neural circuit between the prefrontal cortex and the mediodorsal nucleus of the thalamus. Prog Neurobiol 54: 417-458.

Langman NJ, Smith CGS, Whitehead KJ (2006). Selective serotonin re-uptake inhibition attenuates evoked glutamate release in the dorsal horn of the anaesthetised rat in vivo. Pharmacol Res 53: 149-155.

Li Q, Clark S, Lewis DW, Wilson WA (2002). NMDA receptor antagonists disinhibit rat posterior cingulate and retrosplenial cortices: a potential mechanism of neurotoxicity. J Neurosci 22: 3070-3080.

Lieberman JA (1996). Atypical antipsychotic drugs as a first-line treatment of schizophrenia: a rationale and hypothesis. J Clin Psychiatry 57(Suppl 11): 68-71.

Lorrain DS, Baccei CS, Bristow LJ, Anderson JJ, Varney MA (2003). Effects of ketamine and $N$-methyl-D-aspartate on glutamate and dopamine release in the rat prefrontal cortex: modulation by a group II selective metabotropic glutamate receptor agonist LY379268. Neuroscience 117: 697-706.

Lucas G, Compan V, Charnay Y, Neve RL, Nestler EJ, Bockaert J et al (2005). Frontocortical $5-\mathrm{HT}_{4}$ receptors exert a positive feedback on serotonergic activity: viral transfections, subacute and chronic treatments with $5-\mathrm{HT}_{4}$ agonists. Biol Psychiatry 57: 918-925.

Lucki I (1998). The spectrum of behaviors influenced by serotonin. Biol Psychiatry 44: 151-162.

Maione S, Rossi F, Biggs CS, Fowler LJ, Whitton PS (1997). AMPA receptors modulate extracellular 5-hydroxytryptamine concentration and metabolism in rat striatum in vivo. Neurochem Int 30: 299-304. 
Malhotra AK, Adler CM, Kennison SD, Elman I, Pickar D, Breier A (1997). Clozapine blunts $N$-methyl-D-aspartate antagonistinduced psychosis: a study with ketamine. Biol Psychiatry 42: 664-668.

Malhotra AK, Pinals DA, Weingartner H, Sirocco K, Missar CD, Pickar D et al (1994). NMDA receptor function and human cognition: the effects of ketamine in healthy volunteers. Neuropsychopharmacology 14: 301-307.

Martin P, Carlsson ML, Hjorth S (1998). Systemic PCP treatment elevates brain extracellular 5-HT: a microdialysis study in awake rats. Neuroreport 9: 2985-2988.

Martín-Ruiz R, Puig MV, Celada P, Shapiro DA, Roth BL, Mengod $\mathrm{G}$ et al (2001). Control of serotonergic function in medial prefrontal cortex by serotonin-2A receptors through a glutamate-dependent mechanism. J Neurosci 21: 9856-9866.

Mathé JM, Nomikos GG, Blakeman KH, Svensson TH (1999). Differential actions of dizocilpine (MK-801) on the mesolimbic and mesocortical dopamine systems: role of neuronal activity. Neuropharmacology 38: 121-128.

Maurel-Remy S, Bervoets K, Millan MJ (1995). Blockade of phencyclidine-induced hyperlocomotion by clozapine and MDL 100,907 in rats reflects antagonism of $5-\mathrm{HT}_{2 \mathrm{~A}}$ receptors. Eur J Pharmacol 280: R9-R11.

Meltzer HY (1999). The role of serotonin in antipsychotic drug action. Neuropsychopharmacology 21(Suppl 2): 106S-115S.

Millan MJ (2005). $N$-methyl D-aspartate receptors as a target for improved antipsychotic agents: novel insights and clinical perspectives. Psychopharmacology 179: 30-53.

Millan MJ, Brocco M, Gobert A, Joly F, Bervoets K, Rivet J-M et al (1999). Contrasting mechanisms of action and sensitivity to antipsychotics of phencyclidine versus amphetamine: importance of nucleus accumbens 5- $\mathrm{HT}_{2 \mathrm{~A}}$ sites for PCP-induced locomotion in the rat. Eur J Neurosci 11: 4419-4432.

Moghaddam B (1993). Stress preferentially increases extraneuronal levels of excitatory amino acids in the prefrontal cortex: comparison to hippocampus and basal ganglia. J Neurochem 60: $1650-1657$.

Moghaddam B, Adams BW (1998). Reversal of phencyclidine effects by a group II metabotropic glutamate receptor agonist in rats. Science 281: 1349-1352.

Moghaddam B, Adams B, Verma A, Daly D (1997). Activation of glutamatergic neurotransmission by ketamine: a novel step in the pathway from NMDA receptor blockade to dopaminergic and cognitive disruptions associated with the prefrontal cortex. J Neurosci 17: 2921-2927.

Mohn AR, Gainetdinov RR, Caron MG, Koller BH (1999). Mice with reduced NMDA receptor expression display behaviors related to schizophrenia. Cell 98: 427-436.

Newcomer JW, Farber NB, Jevtovic-Todorovic V, Selke G, Melson AK, Hershey $\mathrm{T}$ et al (1999). Ketamine-induced NMDA receptor hypofunction as model of memory impairment and psychosis. Neuropsychopharmacology 20: 106-118.

Olney JW, Farber NB (1995). Glutamate receptor dysfunction and schizophrenia. Arch Gen Psychiatry 52: 998-1007.

Olney JW, Newcomer JW, Farber NB (1999). NMDA receptor hypofunction model of schizophrenia. J Psychiat Res 33: 523-533.
Park S, Püschel J, Sauter BH, Rentsch M, Hell D (1999). Spatial working memory deficits and clinical symptoms in schizophrenia: a 4-month follow-up study. Biol Psychiatry 46: 392-400.

Patel DR, Young AMJ, Croucher MJ (2001). Presynaptic $\alpha$-amino3-hydroxy-5-methyl-4-isoxazole propionate receptor-mediated stimulation of glutamate and GABA release in the rat striatum in vivo: a dual-label microdialysis study. Neuroscience 102: $101-111$

Paxinos G, Watson C (1986). The Rat Brain in Stereotaxic Coordinates. Academic Press: San Diego.

Schmidt CJ, Fadayel GM (1996). Regional effects of MK-801 on dopamine release: effects of competitive NMDA or 5-HT2A receptor blockade. J Pharmacol Exp Ther 277: 1541-1549.

Sharp FR, Tomitaka M, Bernaudin M, Tomitaka S (2001). Pychosis: pathological activation of limbic thalamocortical circuits by psychomimetics and schizophrenia? Trends Neurosci 24: 330-334.

Suzuki Y, Jodo E, Takeuchi S, Niwa S, Kayama Y (2002). Acute administration of phencyclidine induces tonic activation of medial prefrontal cortex neurons in freely moving rats. Neuroscience 114: 769-779.

Takahata R, Moghaddam B (2003). Activation of glutamate neurotransmission in the prefrontal cortex sustains the motoric and dopaminergic effects of phencyclidine. Neuropsychopharmacology 28: 1117-1124.

Tamminga CA (1998). Schizophrenia and glutamatergic transmission. Crit Rev Neurobiol 12: 21-36.

Tao R, Auerbach SB (2000). Regulation of serotonin release by GABA and excitatory amino acids. J Psychopharmacol 14: 100-113.

Timmerman W, Cisci G, Nap A, de Vries JB, Westerink BHC (1999). Effects of handling on extracellular levels of glutamate and other amino acids in various areas of the brain measured by microdialysis. Brain Res 833: 150-160.

Timmerman W, Westerink BHC (1997). Brain microdialysis of GABA and glutamate: what does it signify? Synapse 27: 242-261.

Tomitaka S, Tomitaka M, Tolliver BK, Sharp FR (2000). Bilateral blockade of NMDA receptors in anterior thalamus by dizocilpine (MK-801) injures pyramidal neurons in rat retrosplenial cortex. Eur J Neurosci 12: 1420-1430.

Väisänen J, Lindén A-M, Lakso M, Wong G, Heinemann U, Castrén E (1999). Excitatory actions of NMDA receptor antagonists in rat entorhinal cortex and cultured entorhinal cortical neurons. Neuropsychopharmacology 21: 137-146.

Wang Y, Goldman-Rakic PS (2004). D2 receptor regulation of synaptic burst firing in prefrontal cortical pyramidal neurons. Proc Natl Acad Sci USA 101: 5093-5098.

Weinberger DR, Gallhofer B (1997). Cognitive function in schizophrenia. Int Clin Psychopharmacol 12(Suppl 4): S29-S36.

Yamamoto BK, Pehek EA, Meltzer HY (1994). Brain region effects of clozapine on amino acid and monoamine transmission. J Clin Psychiatry 55(Suppl B): 8-14.

Yonezawa Y, Kuroki T, Kawahara T, Tashiro N, Uchimura H (1998). Involvement of $\gamma$-aminobutyric acid neurotransmission in phencyclidine-induced dopamine release in the medial prefrontal cortex. Eur J Pharmacol 341: 45-56. 